\title{
Multidisciplinary perspectives on the child's voice in public policy: an introduction
}

\author{
Nicola Berkley and Ruth Lister
}

Abstract: This supplementary issue explores the nature and role of children's voice in public policy from multidisciplinary perspectives. The insights from this issue form part of the evidence base of the British Academy's Childhood Policy Programme, which aims to utilise the research and insights from the social sciences, humanities, and the arts to address issues of fragmentation, inconsistency, and ineffectiveness in childhood policy across the UK.

Keywords: Children, childhood, public policy, voice, rights.

Note on the authors:

Nicola Berkley is a Senior Policy Adviser (Public) at the British Academy.

Baroness (Ruth) Lister of Burtersett is Emeritus Professor of Social Policy, at Loughborough University. She was elected a Fellow of the British Academy in 2009.

(C) The author(s) 2020. This is an open access article licensed under a Creative Commons Attribution-NonCommercial-NoDerivs 4.0 Unported License 
This supplementary issue of the Journal of the British Academy is part of a programme of work at the Academy to explore the role of the state in childhood and new conceptualisations of children in policymaking. Building on research and insights from the social sciences, humanities, and the arts, the Childhood Policy Programme has drawn attention to the fragmented, inconsistent, and uneven policies that produce wildly different outcomes for children depending on their location and background. The development of childhood policy in the United Kingdom is plagued with unresolved issues over how we think of the child as a subject of policy, the interdependence of different policy spheres on outcomes for children, and the divergence of policy through devolution of political decision-making to nations and regions. By casting a multidisciplinary eye onto these issues, the British Academy hopes to reframe debates over childhood in such a way that uncovers steps to improve the coherence of childhood policy in the United Kingdom and deliver policies which support, enhance, and enrich the lives of children.

During its first phase, the Childhood Policy Programme investigated the evolution of childhood policy through a number of research activities, including: policymaking landscape reviews for each of the four UK nations; case studies on approaches across the four UK nations towards children leaving care and childhood poverty; a set of provocations on childhood from a range of disciplinary perspectives; and a series of stakeholder workshops with policymakers, practitioners, and academics.

The publication of these materials coincided with the 60th International Children's Day and thirty years since the UN General Assembly adopted the Convention on the Rights of the Child (UNCRC). The fact that the UK has ratified the UNCRC but that it has not been fully incorporated into domestic law, and that it has been regarded differently in each of the four UK nations, is one of many inconsistencies that has led to a lack of coherence in childhood policy across the UK.

The British Academy's four country case studies, and the two policy case studies, clearly highlight the way in which policy is diverging across the four nations in a range of areas. Whether it is the different ages across the UK for starting school, leaving care, and being held criminally responsible, or the varying strategies and priorities for tackling child poverty, there is a lack of overall coherence in the policies relating to children.

In the various conversations between researchers, policymakers, and professionals working with and on behalf of children that took place in the Childhood Policy Programme over the course of 2019 , one theme that would repeatedly come up was children's voice. What is clear is that children's systematic and sustained participation in the policy process is notable only for its absence. Despite a child's right to freely express views on all matters affecting them and for their views to be given 'due weight', as expressed in the UN Convention on the Rights of the Child (UNCRC), there is no 
systematic practice of giving a meaningful voice to children in public policy in the United Kingdom as a whole, the UK Youth Parliament notwithstanding. While there have been sporadic attempts to bring children's views into debates over issues that affect them, such as school councils and local authority groups for children in care, these largely involve engagement with practices through which policies are enacted and have little impact on the policymaking process.

The second phase of the Childhood Policy Programme is centred on the theme of children's voice, along with two other related themes. The first of these themes focuses on the distinction between being a child and becoming an adult. Policymakers have largely chosen to concentrate their efforts on delivering interventions which aim to improve the prospects for children in their later lives as adults and to prepare them as responsible citizen-workers of the future. The underlying 'becoming' assumptions of public policy may overlook, and perhaps in some cases undermine, the intrinsic value of childhood and the experiences of children. If children's voices matter, it follows that policy could and should define outcomes that matter to children, as distinct from the outcomes that adults decide are the most important for children.

The second related theme explores how children's rights can be applied to policymaking and whether there are rights-based approaches to childhood policy that create better policy coherence. Rights-based policy approaches are one potential solution to the fragmentation and inconsistency in childhood policy across the UK. Children's right to be heard and to have their views respected lies at the heart of the rights enshrined in the UNCRC and is integral to an effective rights-based approach to policy. Such an approach to policymaking would involve finding ways to utilise and amplify children's voices, as well as giving children a way to express their own understanding of rights and how they ought to be enabled by policy.

A number of political theorists have posited the right to participation in decision-making or voice as a crucial citizenship right that underpins the effective realisation of other rights and that recognises the agency of rights-bearers. As Professor David Archard observes in his article in this issue, children are not full citizens with a right to vote (Archard 2020). Arguably this strengthens further the case for their voices to be heard by policymakers in other ways. Moreover, despite the weakness of official channels, many children are already expressing political agency and demonstrating their ability to express their views; indeed, on climate change they have been leading the way. Thus, even though they may not yet be full de jure citizens, they are acting as citizens and can be regarded as de facto citizens whose voices matter. That said, the right to be heard is not tied to citizenship as it represents not just a fundamental right of the child but also a human right to which individuals are entitled by virtue of their humanity, as Magdalena Sepúlveda Carmona, a former UN Special Rapporteur on Extreme Poverty and Human Rights, has underlined (Sepúlveda 
Carmona 2013: para. 20). Moreover, listening with respect to children's views could be seen as a responsibility of adult citizenship.

There is much to debate about the role that children's voice can play in policymaking and, indeed, what impact it might have on the shape, direction, and effect of policy. There are questions over the meaning, implications, and practicality of turning children from passive recipients of policy outcomes into active participants in policy design. This is a problem most suited to a multidisciplinary discussion, as it will no doubt draw on the expertise of a range of academic fields. These will include the creative arts, which hold innovative approaches for engaging children and getting them to express their ideas; psychology and sociology, which can explore the biological, social, and cultural factors affecting development of a child's 'voice' and how their voice is perceived by others; social policy, which can illuminate how intersecting social divisions and social context (including that of the school) shape the ability to participate and be heard; political theory with its insights on citizenship rights and practice; and modern languages and linguistics, which can help us understand the way children use language and how they discursively construct and communicate thoughts, opinions, and demands. In this supplementary issue, we hope to explore children's voice from these perspectives and more, and we shall begin with philosophy.

Philosophy is a perfect disciplinary springboard for this debate, because it helps us to ask challenging but fundamental questions about what it means to be a child, what it means to give a child a voice, and, indeed, why a child should be granted the right to a voice. These questions are explored in our opening article by Professor David Archard, which tries to make sense of the complexity of what it means to listen to a child in the context of Article 12 of the UNCRC. In doing so, he reveals both the value of philosophical analysis and evaluation as well as its limits, opening many opportunities for colleagues in other disciplines to pick up and investigate. While his focus is the voice of the individual child in matters concerning her or him, the questions he poses are for the most part relevant also to children's collective participation in the policy process. And the distinction he makes between 'intrinsic' and 'instrumental' reasons for listening to children has echoes in the tension between treating children as 'beings' and 'becomings', mentioned above.

This supplementary issue of the Journal of the British Academy aims to create and foster an ongoing, interactive dialogue on the various interpretations of 'children's voice'. The issue will explore what exactly it means to listen to children, and to give weight to children's voices, from a range of disciplinary perspectives, encompassing social sciences, humanities, and the arts.

Professor Archard's think piece provides the opener to this dialogue, inviting others to answer questions that arise from his philosophical exploration of the right 
to a 'voice'. Throughout the next six months, until March 2021, this issue of the Journal will subsequently publish responses on a rolling basis to this initial think piece. The intention is that the papers within this series are provocative, sparking discussion and debate, and encouraging a broad range of perspectives that will cumulatively provide innovative insights into the multifaceted theme of children's voice.

We therefore now invite academics and researchers from social sciences, humanities, and the arts to submit a think piece in response to Archard's initial paper. There are several arguments and questions posed by Archard's paper that other disciplinary perspectives could directly respond to, but we would also invite opportunities for complementary perspectives on the nature of children's voice from the evidence and insight of other disciplines. We encourage responses from individuals across all career stages. We would also welcome contributions from professionals working in the policy and practice of children's rights and participation. Journal articles are intended primarily for an academic readership, but because the Journal's disciplinary range is so broad, across the entire spectrum of the humanities and social sciences, articles should be inclusive and accessible to readers who are not specialists in a particular field. Submissions should typically be up to 3,000 words in length. ${ }^{1}$

Insights garnered from this series of papers will form part of the evidence base of the Childhood Policy Programme and will contribute towards the policy development that is an integral part of the second phase of the programme. The think pieces will also form part of the basis for the policy lab series on children's rights that is planned as part of the programme. The policy lab concept aims to bring together the different actors within a policy ecosystem to engage actively with the relevant available evidence and insight on a specific policy issue, and work together to come up with potential evidence-informed policy solutions.

By the conclusion of this phase of the Childhood Policy Programme, the range of activities and outputs that have taken place across the lifespan of the programme will be considered and synthesised in order to develop policy recommendations, centred on the programme's three core themes (children's voice, children's rights, and 'being a child/becoming an adult'). Recommendations will aim to address the challenges identified at the outset of this introduction, namely that childhood policy in the UK is too often fragmented or inconsistent. It is plagued with unresolved issues over how we think of the child as a subject of policy, and complicated by the ways in which the impact of different policy spheres intersect in their impact on children, and by the divergence of policy through devolution of political decision-making to nations and regions.

${ }^{1}$ Further information on the Journal of the British Academy for potential authors can be accessed at https://www.thebritishacademy.ac.uk/documents/2586/JBA-notes_to_authors.pdf 
Professor Archard's article ends with a justification of the philosophical questions it poses: 'good practice only follows from clarity of purpose'. Our hope is that the publication of his article, together with future think pieces, will, through greater clarity of purpose, contribute to making a reality of Article 12 of the UNCRC in a way that furthers children's rights and enhances their childhood, as part of the British Academy's wider childhood policy programme.

Individuals who are interested in contributing a think piece to this issue of the Journal of the British Academy, should in the first instance submit a short abstract of their planned paper (up to 300 words) including details of the disciplinary perspective of children's voice that would be covered, to the Childhood Policy Programme team at childhood@ thebritishacademy.ac.uk. Any enquiries can also be sent to this email address.

\section{REFERENCES}

Archard, D. (2020), 'Hearing the Child's Voice: A Philosophical Account', Journal of the British Academy, 8(s4): 7-15. https://doi.org/10.5871/jba/008s4.007

Sepúlveda Carmona, M. (2013), Report of the UN Special Rapporteur on Extreme Poverty and Human Rights (Geneva, United Nations).

To cite the article: Nicola Berkley and Ruth Lister (2020), 'Multidisciplinary perspectives on the child's voice in public policy: an introduction', Journal of the British Academy, 8(s4): 1-6.

DOI https://doi.org/10.5871/jba/008s4.001

Journal of the British Academy (ISSN 2052-7217) is published by

The British Academy, 10-11 Carlton House Terrace, London, SW1Y 5AH

www.thebritishacademy.ac.uk 